\title{
Die dwaalleer in Kolosse
}

\section{'n Konstruksie van die waarskynlike sosio-historiese en filosofiese konteks}

Wim C. Vergeer

Gereformeerde Kerk

Randfontein-Noord

RANDFONTEIN
Fika J. van Rensburg

Dept. Klassieke Tale \& Semitistiek

Potchefstroomse Universiteit vir $\mathrm{CHO}$

POTCHEFSTROOM

\begin{abstract}
The heresy in Colossians

A construction of the probable socio-historic and philosophic context

In this, the first of two articles, an attempt is made to form the construction of the socio-historic and philosophic context of the heresy against wich Paul warns the Colossians in Colossians 2:8 is attempted. It is argued that this construction is of utmost importance in the correct understanding and interpretation of the letter to the Colossians because of the central position the philosophical heresy and its refutation have in Colossians. The issue of the identity of the pidooopia behind the heresy is addressed and a possible solution is pinpointed. The analysis in this article is preparatory, and forms the hasis of a second article, in which a contemporary socio-historic and philosophic context (namely the New Age Movement) will be analysed and evaluated from a Biblical perspective.
\end{abstract}

\section{Inleiding}

Resente Nuwe Testament-navorsing laat blyk dat die sosio-historiese en filosofiese konteks toenemend belangrik geag word vir die geldige interpretasie van 'n Bybelboek ${ }^{1}$. Met hierdie benadering verskuif die benadering van 'n blote kultuurhistoriese agtergrond of dekor na die konteks waarin 'n Bybelboek ontstaan het. Kenmerkend van hierdie 'nuwe' benadering tot interpretasie is dat die betrokke teks so veel as moontlik as deel van sy ontstaankonteks geëksegetiseer word. Op

1 Nic net oorsese teoloc soos Mocks (1983. 1986), Malherbe (1977), Elliott (1981) cn Theissen (1987) nie, maar ook Suid-Afrikaanse teoloe soos De Villiers (1982, 1984), Botha (1989). Van Aarde (1988) cn Roberts. Vorster, et al (1991) volg hierdic tendens 
hierdie manier word gepoog om die Goeie Nuus van die evangelie in daardie teks beter te verstaan.

Hierdie artikel volg bogenoemde benadering om die dwaalleer waarteen die skrywer ${ }^{2}$ van die Kolossensebrief waarsku (2:8), te ondersoek. Die navorsing word in twee fases afgehandel. In die eerste fase (hierdie artikel) word ' $n$ poging aangewend om die dwaalleer in sy waarskynlike eerste-eeuse sosio-historiese en en veral filosofiese konteks te verstaan ${ }^{3}$. In die tweede fase ('n beplande opvolgartikel) word 'n faset van die hedendaagse sosio-historiese en filosofiese konteks, naamlik die New Age, in die lig van die bevindinge beoordeel.

Belangrik vir die eerste fase van die navorsing is dat ' $n$ hipotese oor die moontlike identiteit van die dwaalleer ontwikkel word. Só 'n benadering tot die verstaan van die Kolossensebrief mag dalk as 'omstrede' of 'spekulatief' beskou word. Roberts (1984:150) meen byvoorbeeld dat 'n mens "goed sou doen" om krities te staan teenoor ' $n$ prosedure waarin Paulus se aanval teen die dwaalleer in Kolosse teen die agtergrond van 'n gekonstrueerde sisteem verstaan word'4

Die ignorering of ontkenning van die belang van die sosio-historiese en filosofiese konteks vir die geldige verstaan van die Kolossensebrief het egter nadelige gevolge. Sodanige ontkenning is waarskynlik die rede waarom navorsers die hoofgedagte van die Kolossensebrief tot dusver hoofsaaklik in die indikatief geformuleer het $^{5}$, en waarom daar in so min studies aandag gegee word aan die praktiese en bevrydende bocdskap wat die evangelie van Jesus Christus in die situasie van die gemeente in Kolosse en in die situasie van hedendaagse gemeentes bring.

Die navorsing vir hierdie artikel is gedoen op grond van ' $n$ bepaalde beskouing oor die taak van die eksegese, naamlik dat die teks van die Nuwe Testament nie

2 Vir die doeleindes van die artikel word aanvaar dat Paulus dic outeur van die Kolossensebrief is.

3 Die sosio-historiese benadering, in onderskeid van dic sosio-wetenskaplike benadering (vgl. Botha, 1989:58-62), word gevolg

Roberts (1988:823-825, 1991:294-320) aanvaar egter self die Joodse mistick as agtergrond vir die dwaalleer in Kolosse (1991:302), en bestee verskeie bladsye van ' $n$ artikel (1991 303-316) om aan te toon hoc die situasie in Kolosse teen 'n Joods-misticke agtergrond sou kon reflektecr.

Vergelyk byvoorbeeld Coetzee (1983:78): "Christus, die Hoof van die Kerk, Koning oor die ganse skepping", Bruce (1972:34): "The Cosmic Christ" en Uitman (1972:7): "Maar de boodschap van de Colossenbrief is: 'mensen ge zijt niet prijsgegeven, want Christus is Hoofd van alles, van alle overheid en macht'". So ook Van der Walt \& Van der Vyver $(1968: 126,127)$ en Smit (1986:9) 
net in sy ontstaan-konteks verklaar moet word nie, maar ook in sy verstaankonteks. Die Goeie Nuus is immers ook vir vandag Goeie Nuus!

\section{Die dwaalleer volgens die Kolossensebrief}

\subsection{Inligting oor die dwaalleer in die Kolossensebrief}

Die dwaalleer in Kolosse word beskryf as 'n sisteem van verstaan ( $\varphi i \lambda$ oooxía) wat deur tradisionele oordrag en onderrig versprei word, en wat lei tot ' $n$ verkeerde beskouing oor die waarheid (2:8). Die dwaalleer word verkondig deur mense wat engele vereer en hulle ophou met visioene (2:18). Hoewel hierdie mense hulleself as "danig nederig" voordoen, is hulle eintlik besig om hulleself in eiewaan te verhef, en los van Christus te lewe (2:18-19).

Die dwaalleer het ' $n$ "skyn van wysheid", maar is ' $n$ "selfgemaakte godsdiens" wat uit menslike gebooie en leerstellings bestaan (2:22-23). Hierdie voorskrifte het onder andere betrekking op eet en drink, aanraak, probeer en proe, feesdae en tye, en streng beheersing van die liggaam $(2: 16,22-23)$.

Die doel vall diè leer was waarskynlik om deur 'n streng voorskriftelike lewe, en deur kontak met engele en magte, deel te verkry aan die volheid $(\pi \lambda \eta \dot{\rho} \omega \mu \alpha)$ van God (2:9).

\subsection{Die strukturele plek van die dwaalleer in die brief}

Uit die opbou van die Kolossensebrief blyk dit dat die weerlegging van die dwaalleer 'n baie sentrale posisie beklee. Na die aanhef $(1: 1-2)$ dank Paulus God vir die geloofsgroei van die gemeente (1:3-8). Hy verduidelik die verlossingswerk in Christus, waarvan hy, Paulus 'n dienaar geword het (1:9-2:5). ' $n$ Deel van hierdie verduideliking is die pragtige lied oor Christus (1:13-20), wat sonder dat die dwaalleer self al aan die orde gestel is, in wese die weerlegging daarvan bevat's.

$\mathrm{Na}$ die verduideliking van die verlossingswerk konkludeer Paulus in Kolossense 2:6-7:

Aangesien julle dan Christus Jesus as Here aangeneem het, moet julle in verbondenheid met Hom lewe, in Hom gewortel en op Hom gebou, vas in die geloof soos julle geleer is, en met dankbaarheid vervul.

6 Op hicrdic aspck sal in 'n moontlike opvolgartikel teruggekom word 
Hierdie konklusie kan om twee redes as die hoofgedagte van die Kolossensebrief beskou word?

* Die voorafgaande verduideliking van die verlossingswerk van God in Christus kulmineer in die beskrywing van die Kolossense se houding teenoor hierdie verlossingswerk ("Julle het Christus Jesus aangeneem").

* Die res van die brief vloei organies voort uit die oproep ("in verbondenheid met Hom [Christus] lewe").

Die uitvoering van laasgenoemde oproep hou in dat gestrewe word na, en die gedagtes gerig word op "die dinge daarbo waar Christus is" (3:1). Hierdie praktyk het twee implikasies 8 .

* 'n Negatiewe implikasie (die breek met die ou mens en sy gewoontes) (3:511),

* en 'n positiewe implikasie (die bekleding met die nuwe mens) (3:12-4:6).

In Paulus se uiteensetting van die positiewe implikasie van die praktyk van 'n lewe in verbondenheid met Christus kan agt verdere oproepe onderskei word:

* $\quad$ "Leef die lewe van die nuwe mens" (3:12-13).

* "Julle moet mekaar liefhê" (3:14).

* $\quad$ "Die vrede van Christus moet in julle lewe die deurslag gee" (3:15a).

* "Wees altyd dankbaar" (3:15b).

* "Die boodskap van Christus moet in sy volle rykdom in julle bly" (3:16).

* $\quad$ "Doen en sê alles in die Naam van die Here" (3:17-4:1)

- in die huwelik (3:18-19)

- in ouer-kindverhoudings $(3: 20-21)$

- in eienaar-slaafverhoudings $(3: 22-4: 1)$.

* "Volhard in die gebed" (4:2-4)

* "Tree met wysheid op teenoor die mense wat nog buite die gemeente is" $(4: 5-6)$.

Die brief word afgesluit in 4:7-18.

7 Ook uit die struktuur wat Robcrts (1984:151) aan dic hand van 'n redevocringsanalisc vasgestel het, kan afgelei word dat die opdrag in Kolossense 2:6-8 sentraal staan in die brief

8 Ander studies wat hierdic tweerlei implikasie aantoon, is Roberts (1984152) en Janse van Rensburg (1984:16). 
Die belang van die dwaalleer word waarskynlik onderstreep deur die feit dat Paulus dit direk na die hoofgedagte ter sprake bring. Hy teken dit as pitooopia wat dreig on gelowiges uit hulle verbondenheid met Christus te ontvoer $(2: 8)$. As tweeledige negatiewe implikasie ${ }^{9}$ van die lewe in verbondenheid met Christus rig Paulus die volgende waarskuwings:

* Pas op dat niemand julle van Cluristus af wegvoer met teorieë en argumente wat misleidend is nie $(2: 8-15)$

* Moenie dat iemand met 'moets' en 'moenies' julle lewenswyse vir julle voorskryf en reguleer nie (2:16-23)

Die dwaalleer word dus as 'n teëpool vir die hoofgedagte (lewe in verbondenheid

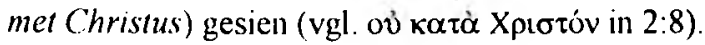

\section{3. 'n Voorlopige betekenisdefinisie van $\sigma \tau o \iota \chi \varepsilon i \tilde{\alpha}$}

Uit die bestudering van die gedagte-opbou word dit duidelik dat die uitdrukking

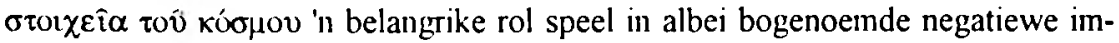
plikasies van die hoofgedagte:

* In die eerste implikasie ("pas op dat niemand julle van Christus af wegvoer met teorieë en argumente wat misleidend is nie" [2:8-15]), word die teorieë

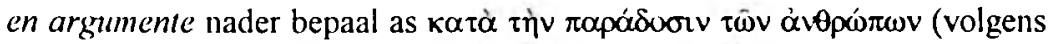

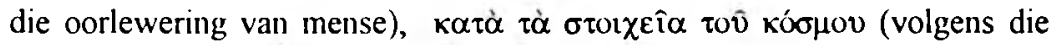

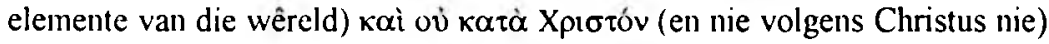
$(2: 8)$.

* In die tweede implikasie (moenie dat iemand met 'moets' en 'moenies' julle lewenswyse vir julle voorskryf en reguleer nie [2:16-23]) word die verbod logies verbind aan die uitspraak dat die gelowiges saam met Christus ge-

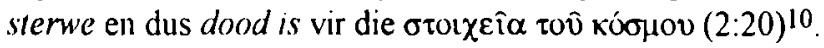

9 Die imperaticf $\pi \varepsilon p t \pi \alpha t \varepsilon \hat{t} \varepsilon$ word in die gedagte-cenheid 2:6-19 gevolg deur drie ander

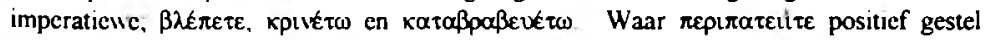

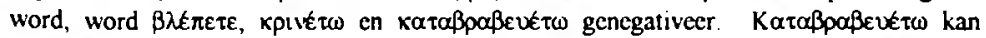
waarskınlık in dic sub-cenheid 2:16-19 as naderverklarend beskou word. Derhalwe word

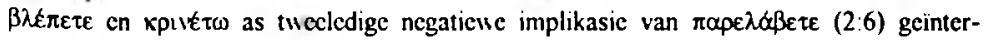
preteer

10 'n Lewe van 'mocts' en 'moenies' word in vers 20 beskrywe as ' $n$ lewe asof julle aan die wéreld behoort. Wic saam met Christus gesterwe het, is dood vir die wereld, en sodoende ook dood vir die orolxeî $\alpha$ van dic wêreld 


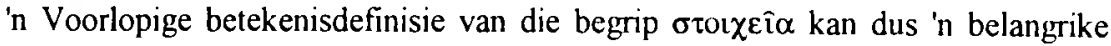
bydrae lewer in die konstruksie van die waarskynlike filosofiese konteks van die dwaalleer in Kolosse.

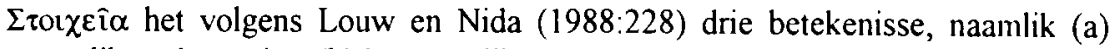
natuurlike substansies, (b) bonatuurlike magte en (c) basiese beginsels.

Die bepaling van $\sigma \tau o \iota \varepsilon \hat{\imath} \alpha$ se betekenis in die Kolossensebrief is geen eenvoudige taak nie. In navorsing sedert die 19de eeu het die klem geleidelik verskuif

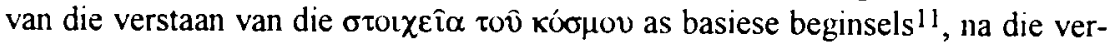
staan as elemente van die wêreld ${ }^{12}$, na die verstaan as bonatuurlike magte ${ }^{13}$. In die navorsing is van 'n groot verskeidenheid buite-Bybelse perspektiewe gebruik gemaak $^{14}$. Die geldigheid van sommige van hierdie perspektiewe is egter onder verdenking:

* In die eerste plek word daar oor die algemeen nie rekening gehou met die ontwikkeling van die eerste-eeuse filosofie nie ${ }^{15}$.

* Tweedens word die sosiale konteks van die Kolossensebrief dikwels (veral in ouer publikasies) buite rekening gelaat.

11 Byvoorbeeld De Wette (1847:43, 44) Ridderbos (1960:172-176) en Bandstra (1964:173) omskry die betckenis enger as basiese beginsels van die godsdiens en die Mosalese wet.

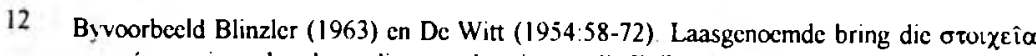
tov xóo $\mu 0 v$ in verband met dic atoombegrip van dic Epikurecrs

13 Byvoorbecld Van Wageninge (1917:1-6) en Bruce (1957:165 c.v., 231 c.v)

14 So byvoorbeeld het Van Wageninge (1917) dic dicreriem, Schippers (1954) dic magiese gelowe van die heidendom, Schlier (1949) die vroce Gnostisisme van Philo, RitschI (1900)

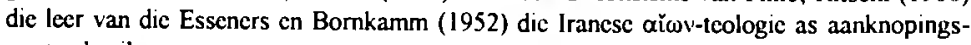
punt gebruik

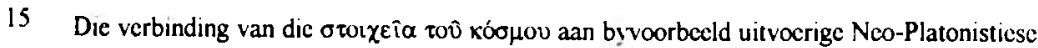
en Gnostiese denkstrukture (Debelius, 1900 en Schlicr, 1949) moct afgewys word ondat sulke strukture waarskynlik ecrs teen 200 n.C ontstaan het (Schweizer, 1970 en Storig, 1972:I:19l) Die ontstaan van die Kolossensebrief is al so vrocg as 60 n.C. gedateer (Coetzee, 1983:76; Roberts, 1984:137). Argumente vir 'n latere datering voer mecstal aan dat 'n tweedegeslag Paulus-groep vir die Kolossenscbrief vcrantwoordelik is (Mccks, 1983:125), maar stuit onses insiens op 4:8 ("Nou skrywe ck met my eic hand Grocte, Paulus.") Paulus se dood (ongevecr 68 n.C.) is dus dic laaste aanvaarbarc datum (Wielenga, 1917:569).

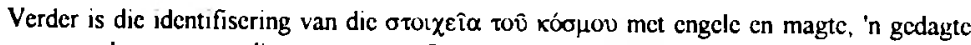
waaroor daar eers na die eerste ccu n.C. getuienis is (vgl Delling, 1964:670-686) Ook hierdie teoric kan in die lig van die ontstaantyd van die Kolossensebrief nic regtens as konteks veronderstel word nic 
* Derdens word deur baie Nuwe-Testamentici uit die oog verloor dat Paulus nie maar net kommentaar lewer op 'n dwaalleer nie, maar dat dit sy hoofdoel is om die evangelie in ' $n$ bepaalde situasie te verkondig 16 .

Die meer finale bepaling van die betekenis of betekenisse ${ }^{17}$ van $\sigma \tau o x \chi \varepsilon i \hat{\alpha}$ in die Kolossensebrief is afhanklik van verskeie ander faktore, waarvan party in hierdie artikel aan die orde gestel word.

\section{Die moontlike verband met Galasiërs}

Dit is ' $n$ vraag of daar ' $n$ verband bestaan tussen die gebruik van die begrip $\sigma \tau 0 \iota \chi \varepsilon \hat{\imath} \alpha$ in die Kolossensebrief (Kol. 2:8, 20) en die Galasiërbrief (Gal. 4:3,9). Alhoewel daar navorsers is wat enige verband afwys (Bandstra, 1964; Ritschl, 1900), is daar te veel ooreenkomste in hierdie tekste om hierdie afwysing sonder meer te aanvaar:

* Albei tekste verwys klaarblyklik na die regulering van menslike gedrag.

* In albei gevalle word die gevaar van die verslawende karakter van die

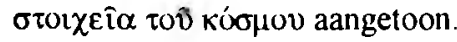

* In albei gevalle word daar geringskattend verwys na menslike oorlewering (Dibelius, 1927:19).

* In albei kan Judaistiese elemente aangetoon word (Lightfoot, 1879; Roberts, 1988, 1991).

* In albei speel engele ' $n$ rol.

Bogenoemde ooreenkomste word verskillend verklaar:

* Delling (1964:282-287) meen dat dit telkens oor dieselfde dwaalleer gaan. In Galasiërs, waar die $\sigma \tau o l \chi \varepsilon \hat{\imath} \alpha$ tov̂ kó $\sigma \mu o v$ baie nou aan die wet van Moses verbind word, toon dit 'n Joodse karakter. In Kolossense, met die klem op

16 'n Oorsig oor die navorsing toon dat daar gevalle is waar dit bloot gaan oor navorsing van dic dwaallecr in Kolosse per se, sonder Inagneming van die brecre raamwerk van dic middelaarskap van Christus waarbinne hierdic dwaalleer deur Paulus ter sprake gebnng word Wanncer Paulus se pastorale benaderingshock in gedagte gehou word, kan dic navorsingsresultate ook meer diensbaar wees in die kerk van vandag

17 Die moontlikheid dat al dric betckenisse in die Kolossenscbricf ter sprake kan wees, moct ook oorweeg word. Dic dwaallecr in Kolosse kon byvoorbocld uitgegaan het van die natuurlike substansies waaruit die kosmos volgens die heersende oortuiging van daardic dae bestaan het Terselfdertyd kon dit hicrdie substansies verhef tot basiese beginsels vir die lewe, en terselfdertyd kon dit sommige van hierdie substansies verpersoonlik as kosmiesc magte en gode. 
"leerstellings met 'n skyn van wysheid" (2:23), vertoon dit 'n meer Griekse karakter.

* Schweizer (1970:258) en Reicke (1951:261) meen dat Paulus in die dwaalleer in Kolosse 'n soortgelyke verslawende praktyk sien as by die Judaïste ten opsigte van die Joodse wet.

* Schlier (1949:116-119, 134 e.v.) meen dat die engele wat in Kolosse aanbid is, dieselfde is as die engele wat in Galasië aan die wet verbind word (Gal. $3: 19)$. Hy meen ook dat hierdie engele dieselfde is as die $\sigma \tau o l \chi \varepsilon \hat{i} \alpha$ tôิ

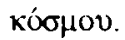

Die filosofiese konteks van die eerste eeu n.C. kan belangrike lig werp op die

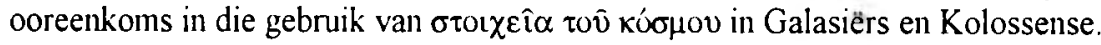

Volgens Meeks $(1986: 60,61)$ het die mense in die eerste eeu n.C. 'n etiese benadering tot die lewe gehad: daar is gestrewe na die volmakte sedelikheid en deugdelikheid van die individu. Die oorwegende mening was dat deug aangeleer kon word, en daarom het baie klem op die regte optrede en gedrag geval. Slegs deur voortdurende oefening en askese kon daar vooruitgang wees op pad na die volmaakte sedelikheid. Die hoogste doel van hierdie etiese lewenstyl was om soos die gode te wees (vgl. Duvenage, s.j.:28; Hendriksen, 1964:110; Meeks, 1986:41-45).

Die groot gevaar vir die Christendom was dat die iniddelaarskap van Christus hierdeur in gedrang kon kom. Lidmate kon die volmaakte sedelike gedrag, in plaas van die middelaarskap van Christus, as heilsmiddel begin sien. In Galasië kon die onderhouding van die Joodse wet, en in Kolosse die lewe volgens die

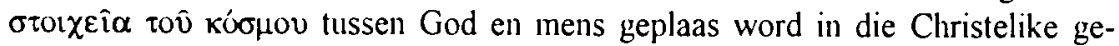
dragsleer.

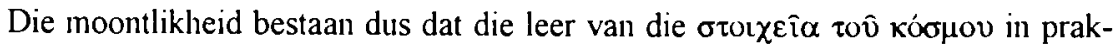
tyk uit gedragsvoorskrifte bestaan het - voorskrifte gemik op die bereiking van die hoogste ideaal van daardie tyd (naamlik die volmaakte sedelike individu, gelyk aan die gode). In Galasië was hierdie voorskrifte waarskynlik meer Joodswettisisties gekleur, en in Kolosse meer Grieks-filosofies.

\section{5. 'n Konstruksie van die dwaling}

\subsection{Die omvang van die dwaling}

Dit is onwaarskynlik dat die dwaalleer wat in die Kolossensebrief ter sprake kom, net tot Kolosse beperk sou wees. Kolosse was nie 'n geïsoleerde gemeenskap nie, dit was baie naby aan Laodisea en Hierapolis geleë, en op die hoofweg van die hawestad Efese na die binneland van Asië. 
Navorsing toon dan ook dat die dwaalleer waarteen Paulus in die Kolossensebrief waarsku, vernoedelik ook in Aleksandrië 18 , Galasië19, Qumran ${ }^{20}$ en Persië21 invloed gehad het.

Die feit dat Paulus die Kolossensebrief (wat grootliks apologeties van aard is) na Laodisea aanbeveel $(4: 16)$, is 'n verdere aanduiding dat die dwaalleer waarskynlik ook daar voorgekom het. Heelwat navorsers 22 is van oortuiging dat die dwaalleer waarteen Paulus skrywe, 'n wydaanvaarde en bekende lewens- en wêreldbeskouing van daardie tyd was.

\subsection{Die sosiale status van die dwaling}

'n Belangrike saak vir die verstaan van die Kolossensebrief is die vraag na die sosiale status van die dwaling. Was dit 'n binne-kerklike dwaling, 'n filosofie wat die gemeente van buite bedreig23 het, of 'n kombinasie van die twee? Die tcıstaan van die posisie van die gemeente in die gevestigde sosiale strukture van destyds kan moontlik 'n antwoord bied.

In die Grieks-Romeinse wêreld van die eerste eeu n.C. was daar twee sosiale strukture waarmee die Christelike gemeente vergelyk kon word: die gemeente kon 'n ooreenkoms toon met ' $n$ vereniging ${ }^{24}$ of ' $n$ filosofiese skool ${ }^{25}$. Vrae wat

18 Woed (1971:31), Hendriksen (1964:109) en Hanson (1974:6) merk tendense van die dwaling in Kolosse op in die geskrifte van Philo van Alcksandric

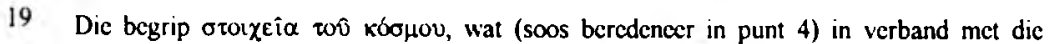
dwaallocr in Kolosse gebring kan word, kom ook in Galasiêrs 4:3 cn 9-11 voor

20 Godet (1887:170-172), Weed (1971:31) en Hendriksen (1964:109) wys op die oroenkomste tussen die leerstellings van die Esseners en die dwaalleer in Kolosse

Dibelius (1927:29) herken trekke van die Persiese godsdienste in dic dwaalleer in Kolosse

22 Woed (1971:31); Caird (1976:161); Godet (1887:169); Bornkamm (1952:12-15); Dibelius (1927:28)

23 Roberts (1988:813) verkies om die meer neutrale begrip bedreiging cerder as dwaalleer te gebruik

In die Gricks-Romeinse wêreld was daar heclwat sulke vrywillige verenigings Dit het bestaan uit verskıllende belangegroepe wat na 'n verskeidenheid van sake omgesien het (byvoorbceld die behoorlike begrafnis van lede) Die Romeinse owerheid het uit vrees vir sameswerings sulke verenigings dikwels met agterdog bejeen en selfs verbied (vgl Mecks. 1986:113)

Die belangrikste filosofiese skole was dic Stoissne, dic Platoniste, dic Skepticı en die Epikurcers. Elkwen van hierdic skole word kortliks in 5.3 .3 van hierdic artikel bespreck 
rondom die Christelike gemeente as sosiale struktuur kon ontstaan het, was die volgende: Indien die Christene 'n vrywillige vereniging is, waarom het hulle 'n vonn van inisiasie (die doop) geliad, en waarom lewe die lede volgens 'n vasgestelde etiese gedragskode? Indien die Christene 'n filosofiese skool is, wat is hulle filosofie, en waarom vergader hulle soos 'n vereniging? Binne die destydse sosiale strukture lyk die Christelike gemeente dus soos 'n vereniging, maar tree op soos 'n filosofiese skool.

Hierdie waarskynlike sosiale 'identiteitskrisis' moes druk van binne en van buite op die gemeente in Kolosse geplaas het om iewers binne die gevestigde en aanvaarde sosiale strukture 'n plek te vind. Binne hierdie waarskynlike konteks kan aanvaar word dat sommige van die gemeentelede hul sosiale identiteit as 'filosofiese skool' probeer vind het.

Hierdeur ontstaan daar egter vrae oor die rol wat 'n gevestigde filosofie in die Christelike gemeenskap behoort te speel. Dit wil voorkom of die dwaalleraars 'n vorm van versmelting tussen Christelike waarhede en tradisionele praktyke gepropageer het.

In die Kolossensebrief reageer Paulus teen versmelting. In sy reaksie het hy waarskynlik daardie spesifieke filosofiese tradisie wat in die versmelting betrokke was, in die $\operatorname{oog}^{26}$.

\subsection{Die bron en identiteit van die dwaalleer}

Vervolgens word gepoog om die moontlike filosofiese tradisie nader te bepaal die filosofiese tradisie waarin sommige van die lidmate van die kerk in Kolosse vermoedelik sosiale identiteit wou vind, en waarteen Paulus in die Kolossensebrief reageer. Die volgende kort oorsig oor die destydse kosmologie en 'n vergelyking van die bekendste filosofiese tradisies van die eerste eeu n.C. is verhelderend.

\subsubsection{Die oorsprong van die kosmologie}

Empedokles 27 (494-434) word algemeen erken as die grondlegger van die kosmologie van die Griekse beskawing (Schweizer, 1970:250). Hy onderskei vier

26 Dit lyk of Paulus in dic Kolossensebrief die strategie volg om eers (1:1-2:23) die versmelting te kritiseer (onder andere deur die genoegsaamheid van Christus te verkondig [1:13-23, 2:9], en die 'menslikheid' [2:8] en 'uitgediende voorlopigheid' $[2: 17]$ van dic tradisie aan te toon), en dan die ware identiteit van die gemeente te bevestig as 'Christus' $(3: 1-4: 18)$, ("hier is Christus alles in almal" [3:11]) en as "volk van God' ("Julle is dic uitverkore volk van God wat Hy baie lief het" [3:12]) 
basiese elemente waaruit die hele kosmos saangestel is, naamlik water, aarde, lug en vuur. Hierdie elęmente was in voortdurende sikliese beweging.

Kosmiese beweging word beurtelings bepaal deur twee kragte: liefde en haat (O’Brien, 1969:1). Wanneer haat regeer, verhoog die beweging en dryf die elemente in konsentriese sirkels verder uit mekaar. Wanneer liefde regeer, verminder beweging, en word al die elemente saamgevoeg in 'n enkele eenheid, naamlik 'die sfeer'. Alternatiewe wêrelde van toenemende haat of liefde is deel van 'n eindelose opeenvolging waarin die 'eenheid' en 'veelheid' van die kosmos tot uitdrukking kom.

Van al die elemente is vuur die hoogste, die goddelike element (Allen, 1966:50: frag. 6). Die sterre verteenwoordig goddelike wesens, omdat hulle uit suiwer vuur bestaan. Vuur verteenwoordig terselfdertyd die 'gees' in die mens - die gees wat sy edelste eienskap is (Spier, 1959:23). Die mens is ' $n$ samestelling van dieselfde elemente as die kosmos en ervaar as mikrokosmos dieselfde beweging as die kosmos.

Empedokles se kosmologie beïnvloed sy antropologie bepalend. Die mens is op reis deur die verskillende elemente met die doel om die hoogste en goddelike element te bereik. Eers daar vind die $\psi v x \eta$ rus en vrede en word dit in die geselskap van die gode opgeneem (Schweizer, 1970:252). Telkens wanneer die $\psi v x \eta ́$ nie daarin slaag om die hoogste element te bereik nie, word dit gereinkanneer (Vorländer, 1971:I:39).

Empedokles meen die mens kan die goddelike element bereik deur kontak te maak met 'n gevalle goddelike wese (genoem 'n $\delta \alpha i \mu \omega v$ ) (Diels, 1903: frag. 59, 115). Saam met hierdie $\delta \alpha i \mu \omega v$ moet 'n reinigingsproses ondergaan word. Die reinigingsproses bestaan uit askese, onthouding van die sinlike en liggaamlike beheersing en nederigheid (Sassen, 1949:28).

Die teologiese belang van die kosmologie van Empedokles word soos volg deur O'Brien (1969:250) saangevat: "Empedocles' theory of cyclic succession for the first time provides a place for otherworldliness within a fully philosophical system."

27 Omdat daar slegs 'n paar fragmente van Empodokles se geskrifte oorgebly het, moet 'n logiese oorsig oor sy waarskynlike standpunt uit meestal sekondêre anticke bronne gekonstrucer word 
'n Stroom van religieuse ervarings, wat tot op daardie stadium vir die grootste gedeelte vreemd was aan die Ioniese en Eleatiese denkpatrone ${ }^{28}$, word deur Empedokles se kosmologie moontlik gemaak:

* Die gedagte van die lewe na die dood.

* Die bestaan van bonatuurlike wesens.

* Die bestaan van die goddelike in sowel die kosmos as die mens. ${ }^{29}$

* Die moontlikheid dat die mens kontak kan liê met, en invloed kan uitoefen op die bonatuurlike wêreld.

* Die gedagte van reïnkarnasie.

* Die kenteoretiese oortuiging dat selfkennis en godskennis ooreenstem. ${ }^{30}$

* Die moontlikheid van menslike selfverbetering tot goddelikheid. ${ }^{31}$

Alhoewel Empedokles ongeveer 500 jaar voor die waarskynlike ontstaantyd van die brief aan die Kolossense geleef het, het sy standpunt, en veral die kosmologiese basis daarvan, bly voortbestaan. In die eerste eeu n.C. is sy standpunt grootliks uitgebrei en verwerk ${ }^{32}$ (veral ten opsigte van die verbinding van die elemente en die kragte agter die elemente). In wese was dit egter steeds dieselfde kosmologie wat die wêreldbeeld bepaal ${ }^{33}$ en die heersende filosofiese strominge ten grondslag gelê het. Uit hierdie gedeelde kosmologie het die moontlikheid van verskeie gemeenskaplike temas na vore getree.

28 Empedokles sc opvatting word beskou as dic afsluiting van die loniese natuurfilosofic wat gesock het na 'n "oerstof waaruit alles ontstaan het (Störig. 1972:I:128)

Jacger $(1913: 53,54)$ meen dat Empedokles dic oorsprong van hicrdic idec van ' $n$ connate pneuma is - 'n gedagte wat later voortlecf in die werke van Aristoteles (byvoorbecld De Anima)

Reiche (1960:41) beskou dit as 'n kenteoreticse uitvlociscl van Empedokles se gedagte dat die goddelike in sowel die kosmos as dic mens bestaan

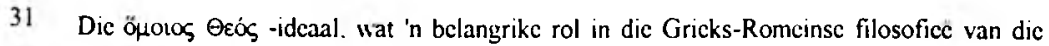
eerste eeu n.C gespecl het, vind filosoficse begronding in dic kosmologic van Empedokles (Mccks, 1986:60)

Byvoorbecld deur Philo, die Rabbync, Simon Magnus en Plutarchos (vgl. Schwcizer, 1970:251).

Van de Kamp (1987:303-317) toon effekticf aan dat die kosmologic die wêreldbecld en dic teologic ingrypend beinvloed 


\subsubsection{Gemeenskaplike temas in die eerste eeu n.C.}

Die verskillende Grieks-Romeinse filosofiese tradisies van die eerste eeu n.C. het verskeie gemeenskaplike temas gehad (Meeks, 1986:60, 61). Die belangrikste hiervan is die volgende:

* Elke tradisie se hoofdoel is 'n 'goeie' lewe

* Die 'goeie' lewe is vir almal hoofsaaklik 'n etiese vraagstuk.

* Almal stem saam dat die 'goeie' lewe bereik word deur die rede, alhoewel die verskillende tradisies oor die praktyk verskil.

* Almal stem saam dat die 'goeie' lewe ' $n$ 'natuurlike' lewe is, maar die verskillende tradisies verskil oor wat 'natuurlik' is.

Hierdie gemeenskaplikhede het 'n algemeen aanvaarde en populêre eklektiese tradisie moontlik gemaak (vgl. 6.4).

\subsubsection{Die belangrikste filosofieë van die eerste eeu n.C.}

Vier hooftradisies kan in die eerste eeu n.C. onderskei word:

\subsubsection{Die Stoïsyne}

Die Stoïsyne het die Platoniese geloof verwerp dat daar onafhanklik van mense en onafhanklik van die sigbare wêreld, ideë bestaan wat die voorbeelde vir hierdie wêreld is. Hulle glo in ' $n$ enkelvoudige wêreld, wat deur ' $n$ 'wêreldsiel' bestuur word. Hierdie 'wêreldsiel' is die rede. Die rede deurdring alles op aarde, bepaal die lot van alles, en sorg dat alle dinge hulle voorbeskikte bestemming bereik.

Die bereiking van die 'goeie' lewe is vir die Stoïsyne afhanklik van die mens se onderwerping aan hierdie voorbeskikte lot ${ }^{34}$. Omdat alles voorbeskik is, is daar 'n beperkte aantal dinge waarop die mens invloed kan uitoefen; die res val buite sy beheer. Die mens se taak is om die $\psi v x \eta$ vry van enige hartstogte en emosies te hou. Selfbeheersing en askese is belangrike deugde in die strewe na hierdie ideaal. Die 'natuurlike' lewe is die doelbewuste keuse van die individu om in ooreenstemming met sy voorbeskikte lot te lewe. Selfs die dood is in hierdie opsig 'natuurlik' en nie iets negatiefs nie. Na die dood is daar geen oorlewing van

'n Becld wat aan Zeno toegesknf word. verklaar hierdie lewenstyl in terme van 'n hond wat aan ' $n$ wa vasgemaak is Dic hond gaan saam met die wa, of hy nou wil of me Die 'gocie' leue vir die hond is as hy' alle ander begeertes prysgee, en cenvoudig met die wa saamgaan 
die భvхи́ nie (vgl. Meeks, 1986:45-50; Duvenage, s.j.:30,31; en Störig, 1972:1: $181-186)$.

\subsubsection{Die Platoniste}

Vir die Platoniste was dit die doel van die 'goeie' lewe om soos die gode te wees. Hierdie doel word bereik deur opvoeding. Deug kan dus aangeleer word.

Volgens die Platoniste het die $\psi v \chi \eta \dot{~ u i t ~ t w e e ~ d e l e ~ b e s t a a n: ~ d i e ~ e e n ~ d e e l ~ g o d d e l i k ~}$ en rasioneel, die ander irrasioneel en emosioneel. Deug word aangeleer wanneer die rasionele die irrasionele kultiveer. Vooruitgang op hierdie pad vra voortdurende oefening, selfbeheersing en askese.

Ander bekende Platonistiese standpunte was die volgende: die skepping van die wêreld aan die hand van ewige ideè, die onsterflikheid van die $\psi v x \eta ́$ en die reïnkarnasie van diegene wat in die lewe faal om die irrasionele deel van die $\psi v 0 x$ te kultiveer (vgl. Meeks, 1986:43-45; Störig, 1972:I:143-163; en Spier, 1959:3643).

\subsubsection{Die Skeptici}

Die Skeptici se leer trek saam in die volgende gedagte: hoe minder afhanklik die mens van stoflike dinge is, hoe nader is hy aan 'n god. Op grond van hierdie uitgangspunt het die Skeptici onversorgd deur die lewe gegaan en het hulle meestal van bedelgeld gelewe. Volgens lulle kan die 'goeie' lewe bereik word deur oefening en inspanning. Die oefening moet gemik wees op 'n eenvoudige lewe, met behoefte aan so min as moontlik dinge. Die prysgawe van alle besittings was vir hulle die begin van die wysheid.

Die Skeptici het 'n hoë premie gestel op hulle reg om onafhanklik van gevestigde waardes en aanvaarbare gedrag te leef. Hulle het slegs belanggestel in die lewenspraktyk; daarom het hulle hulle ook nie gesteur aan die openbare mening nie (vgl. Meeks, 1986:52-56; Störig, 1972:I:188).

\subsubsection{Die Epikureërs}

In die eerste eeu n.C. was die Epikureërs feitlik by almal bekend as 'anti-sosiale genotsoekers'. Hulle het gesinstipe gemeenskappe gevorm en 'n materialistiese lewens- en wêreldbeskouing uitgeleef. In reaksie op die metafisika van Plato en Aristoteles het hulle die meganistiese atoomleer van Demokritos aanvaar. Hulle het daarna gestreef om die mens te bevry van die bygeloof dat die wêreld op 'n bonatuurlike manier ontstaan het en beheer word. Hulle wou nie anti-godsdienstig wees nie, maar wou tuisbring dat indien daar gode is, hulle nie verant- 
woordelik is vir die ontstaan en bestaan van dinge nie. Van die gode het 'n mens niks te vrees en niks te verwag nie

Die Epikureërs was gekant teen askese, en het geglo dat alles wat genot verskaf, goed is. Genot is gedefinieer as 'die afwesigheid van pyn'. In teenstelling met die ander filosofiese tradisies van hulle tyd, het die Epikureërs nie geleer dat die 'goeie' lewe moeilik is om te bereik nie. Vir die 'goeie' lewe moes die mens homself bevry uit die 'gevangenis' van berocpsbelange en politiek. Hy moes sy natuurlike behoeftes uitleef deur alles te doen wat genot verskaf (vgl. Meeks, 1986:56-60; Duvenage, s.j.:28-30; Störig, 1972:186-188).

\subsubsection{Evaluering}

In die soektog na die moontlike bron van die dwaalleer van die Kolossense, lyk die vier belangrikste filosofiese tradisies na onwaarskynlike kandidate

* Die Epikureërs met hulle weersin in askese, asook luul apatiese houding teenoor gode en die bonatuurlike, pas nie in binne die raamwerk van die dwaalleer in Kolosse nie. Die dwaalleer se streng heheersing van die liggaam (2:23) en aanhidding van die engele (2:18) sou vir die Epikureërs onaanvaarbaar wees.

* Ook die Skeptici kwalifiseer nie. Hulle lewenstyl klop nie met die danige nederigheid $(2: 18,23)$ van die dwaalleer in Kolosse nie. Die individualistiese aard van hierdie filosofiese skool maak dit verder ook ongeskik vir die identiteit waanna die gemeente in Kolosse vermoedelik gesoek het.

* Alhoewel sommige navorsers wel 'n verband tussen die vroeë Christelike gemeenskappe en die Stoisyne sien (vgl. Duvenage, s.j.:31), lyk dit tog of ook die Stoïsyne nie aan die dwaalleer in Kolosse verbind kan word nie. Hulle fatalistiese lewenshouding ten opsigte van dié dinge wat buite die mens se beheer is, strook nie met die dwaalleer se ywerige nakoming van voorskrifte met 'n godsdienstige doel nie $(2: 16,23)$.

* Die Platonisme is die mees waarskynlike konteks vir die dwaalleer in Kolosse. In die Platonisme is daar ruinte vir die bonatuurlike, die asketiese en voorskriftelike lewenstyl en die selfgemaakıe godsdiens $(2: 18,23)$. Terselfdertyd moet egter in gedagte gehou word dat die Platonisme, veral die latere Akademie, 'n komplekse tradisie was. 'n Onvattende kennis van, en insig in die leerstellings van hierdie skool was waarskynlik buite bereik van die deursneemens. Die Platonisme was in die eerste eeu n.C. reeds lankal verby sy 'hoogtepunt', en die leiersfigure van die tweede en derde Akademie het hulle besiggehou met die verdediging en uitbreiding van die 'geestelike erfgoed' van Plato. In die bestryding van die dogmatisme van die Stoïsyne het lulle al hoe meer na die Skeptisisme geneig (vgl. Bevan, 1965:91, 98; Sassen, 1949:141, 142.) 
'n Beslissende woord oor die filosofiese konteks van die dwaalleer in Kolosse kan dus nog nie gespreek word nie. Verskeie ander sosio-historiese faktore van die eerste eeu n.C. moet eers in berekening gebring word.

\section{Enkele tersaaklike sosio-historiese faktore}

In die eerste eeu voor en na die geboorte van Christus het ingrypende sosiale en filosofiese veranderings in die Westerse wêreld plaasgevind. Enkele van hierdie veranderings, wat moontlik 'n invloed op die filosofiese konteks van die dwaalleer in Kolosse uitgeoefen het, word vervolgens kortliks bespreek.

\subsection{Die besef van die opvoedingswaarde van die Griekse kultuur}

Die opvoedingswaarde van die Griekse kultuur en filosofie is al hoe meer deur die Romeine besef, veral die ideaal van volmaakte deugdelikheid (wat volgens die Griekse filosofie aangeleer kon word) het tot die Romeine gespreek. Nero stel in 59 n.C. die Griekse spele in Rome in. Romeinse keisers soos Augustus, Traianus en veral Hadrianus (wat as gevolg van sy voorliefde vir die Griekse kultuur, die bynaam Graeculus ontvang het) was positief ingestel teenoor die Griekse filosofie. 'n Proses waardeur die Griekse kultuur en filosofie verinternasionaliseer sou word, is hierdeur in beweging gebring (vgl. Vorländer, 1971:1:135, 143; Cary \& Scullard, 1975:480).

\subsection{Die opbloei van die Griekse letterkunde}

Die Romeinse belangstelling in die Griekse kultuur was een van die vernaamste redes vir die opbloei van die Griekse letterkunde in die eerste eeu voor en na Christus. Bundels kort opstelle oor vrae van algemene sosiale belang (byvoorbeeld Plutarchos se "Moralia"), en sy kort lewensketse van belangrike Griekse figure, was gewilde leesstof. Romeinse skrywers ${ }^{35}$ het bekende Griekse werke uitgelê en gekritiseer (selfs daarmee gespot), maar het tog sodoende die Griekse kultuur en filosofie gepopulariseer (vgl. Cary \& Scullard, 1975:311, 312, 480; Vorländer, 1971:1:144).

\subsection{Die ineenstorting van die mitologie as religie}

In die eerste eeu voor en na Christus het die mens riglyne vir die lewe gesoek wat uitgaan bo die ou mitologie - die enkel transendente godsbegrip het nie meer be-

Byvoorbeeld Cicero (106-43v C.) in De Officis, De Finibus, Tasculanae, Disputationes, De Senecture en De Amicitia. Ook Musonius Rufus, Sencca, Cato en Markus Brutus gebruik die Grickse kultuur om dic regte eticse lewenswandel te illustreer 
vredig nie. Die mens het homself nie langer beskou as iemand wat uitgelewer is aan die willekeur van die gode nie: hy wou self invloed op sy lot uitoefen. Daar was 'n behoefte aan die logiese en wetenskaplike verklaring van verskynsels. Die mens wou 'tuis' voel in die kosmos, en nie bedreig nie (vgl. Bevan, 1965:92, 96 e.v.; Sassen, 1949:109).

\subsection{Die versmelting van filosofieë}

Die ineenstorting van die mitologie as religie het 'n leemte in die destydse denke gelaat. Die filosofie (veral dié van die Stoïsisme en die Platonisme) met sy duidelike stellings en kategoriese gedragsreëls, was die beste geplaas om hierdie leemte te vul. Die 'hoë' en 'droë' skolastiese denke van die tradisionele filosofieë was egter te wetenskaplik vir die deursneemens; daarom het daar mettertyd meer populêre filosofiese sisteme ontstaan - sisteme bekend as die eklektiese filosofieè.

Hierdie sisteme het bestaan uit 'n versmelting van die gewildste gedagtes van verskillende filosofiese stromings, en was gemik op die samevoeging van algemene oortuigings tot 'n filosofiese eenheid. Die doel was ' $n$ 'algemene filosofie' as ondogmatiese religie, waarin alle mense kon deel (vgl. Bevan, 1965: 91-98, Störig, 1972:I:189-191).

Die 'algemene filosofie' wat in die eerste eeu n.C. gedien het as populêre, ondogmatiese religie, moet oorweeg word as 'n waarskynlike filosofiese konteks vir die dwaalleer in Kolosse. Een van die belangrikste verteenwoordigers van hierdie 'algemene filosofie' was Posidonius van Apamea.

\section{Posidonius van Apamea}

Posidonius is in ongeveer 135 v.C. in Apamea ${ }^{36}$ gebore. Hy verlaat sy tuisdorp op jeugdige leeftyd en studeer onder die bekende Stoïsyn Panaetus, die hoof van die Stoisynse skool te Atene. Na sy opleiding stig hy 'n eie filosofiese skool te Rhodos. Hier word hy 'n gesogte leenneester en gesiene burger. Hy sterf in 51 v.C. bekendheid sou verwerf) geografies betreklik naby aan Kolosse gelee is, is genoeg rede om sy filosofie decglik te oonweeg as konteks van dic dwaallecr in Kolossc. 
Min van Posidonius se werk het behoue gebly: die meeste is fragmente uit aanhalings deur sy studente en bewonderaars. Navorsers ${ }^{37}$ meen egter dat hy 'n geweldige invloed uitgeoefen het op die voorste denkers en skrywers van die eerste eeu n.C - dit is onder andere bekend dat Cicero en Pompeius van sy leerlinge was. Ook Philo van Aleksandrië, Diodorus, Manilius, Seneca, Varro, Dio Chrysostomos en Plutarchos is grootliks deur hom beïnvloed. Sassen $(1949: 138,139)$ meen dat Posidonius die verbinding vorm tussen Griekeland en Rome, en dat sy filosofie die voorloper was van die godsdiens-wysgerige stelsels wat later in die Neo-Platonisme tot uitdrukking sou kom.

Die waarde van Posidonius lê nie in oorspronklike denke soos dié van Plato en Aristoteles nie. Hy was eerder die een wat die populêre filosofiese oortuigings van sy tyd tot 'n eenheid saamgevoeg het. Hy het die filosofiese uitdrukkings van die gewone mense van sy tyd saamgevoeg en geformuleer. Bevan (1965:94) toon oortuigend aan dat sy werke meer as enigiemand anders s'n die algemene GrieksRomeinse denke van die eerste eeu n.C. verteenwoordig.

Posidonius het aan die voorpunt gestaan van die filosofiese beweging wat die religieuse leemte in die destydse denke wou vul. Volgens Sassen (1949:139) wou hy die religieuse bewussyn van die samelewing herstel, maar dan op só 'n manier dat mense nie daardeur bedreig gevoel het nie. Bevan (1965:98) formuleer die doel van Posidonius se filosofie waarskynlik die beste as hy sê: "to make man at home in the universe." 38

Die moeilike (en omstrede) taak om Posidonius se filosofie te konstrueer, is al deur 'n paar navorsers ${ }^{39}$ aangepak. Om die moontlike filosofiese konteks van die dwaalleer in Kolosse enigsins te probeer verhelder, word 'n kort samevatting van hulle pogings vervolgens aangebied.

\subsection{Kosmologie}

Die Stoïsyne het die kosmos verstaan as een groot stad, waarvan sowel mense as gode burgers is (Bevan, 1965:102, 103). Hierdie monistiese wêreldbeeld het teenoor die dualisme van Plato en Aristoteles gestaan. In die filosofie van die Stoïsyne

Barrow, 1967:47 e.v., Vorlander, 1971:I:144; Cary \& Scullard, 1975:312; Sassen, 1949: 138-144, 148, 154, 175; Bevan, 1965:85; Brenk, 1977:268

Dit is opmerklik dat die tema van Paulus se brief aan die Kolossense gemaklik in dieselfde terme beskryf sou kon word. Die kosmos, die mens se plek in die kosmos en die kosmiese betekenis van Christus is temas wat in die Kolossensebrief sterk na vore tree

Bake (1810); Jacoby (1926); Edelstein (1936); Bevan (1965); Edelstein \& Kidd (1972) 
was daar geen ruimte vir teologie of die sogenaamde 'eerste filosofie' nie. Slegs die fisika kon alles verklaar.

Posidonius het ook van hierdie vertrekpunt uitgegaan. Saam met die ander Stoisyne het hy (Diogenes Laertius, Lives VII,134) aanvaar dat daar twee basiese beginsels in die kosmos bestaan, naamlik ' $n$ aktiewe en 'n passiewe. Die aktiewe beginsel is die goddelike, die rede; die passiewe is die materie. Die goddelike bestaan in elke deel van die materie, skep dit en bestem dit.

Posidonius verskil egter van die Stoïsyne ten opsigte van die moontlikheid dat materie as suiwer materie bestaan. Hy beweeg nader aan Aristoteles as hy beweer dat materie slegs in denke as suiwer materie bestaan, maar in werklikheid altyd 'n bepaalde vorm of kwaliteit het (Edelstein, 1936:290, 291).

Hierdie standpunt beinvloed sy beskouing oor die goddelike naamlik dat die goddelike as't ware gebind is aan die materie: die hele wêreld is die materie van die goddelike (Diogenes Laertius, Lives VII,148). Teenoor Plato (Demiurg as skepper) en Aristoteles (onbeweeglike beweger) wat 'n transendente beskouing oor die goddelike leer, leer Posidonius dus die immanensie van die goddelike in die kosmos. Hierdie standpunt het belangrike implikasies:

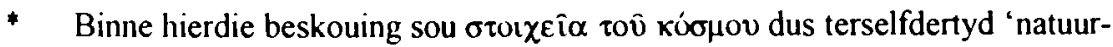
like substansies', 'goddelike elemente' en 'basiese beginsels' kon beteken, sonder om mekaar noodwendig te weerspreek.

* Hierdie standpunt oor die immanensie van die goddelike laat Posidonius nie toe om saam met die res van die Stoïsyne die skepping en vernietiging van die kosmos te leer nie. Omdat die goddelike in die kosmos is, het dit geen begin of einde nie (Edelstein, 1936:293).

* Hierdie standpunt maak die gedagte van 'selfkennis is godskennis' moontlik (Heinemann, 1968:I:69).

* Hierdie standpunt maak die gedagte van 'selfliefde is alles-liefde' moontlik (Heinemann, 1968:I:79).

Meer as enige ander standpunt van Posidonius is dit sy leer oor die immanensie van die goddelike in die kosmos, wat die mens van die eerste eeu n.C. laat 'tuis voel' het in die kosmos.

In die kosmos is warmte en lig die formerende en bewegende element. Hierdie element noem Posidonius $\psi v x \chi \dot{\eta}$. Alles in die kosmos word daardeur lewe gegee (Diogenes Laertius, Lives VII,157). Selfs die sterre, wat Posidonius 'gode' en 'demone' (Diogenes Laertius, Lives VII,148) noem, word daardeur gelei. Deur hierdie leer gee Posidonius 'n rasionele basis vir die astrologie, iets wat sy filosofie veral onder die Romeine gewild gemaak het (Bevan, 1965:115). 


\subsection{Antropologie}

Ook ten opsigte van die etiese kombineer Posidonius die gewildste teorieë van sy tyd. Hy beweeg weg van die Stoïsynse monistiese antropologie. Saam met die Stoïsyne erken hy dat die rede die goddelike fragment in die mens is, maar ontken dat dit die enigste heersende beginsel vir die $\psi v \chi \eta \dot{n}$ is. Saam met die rasionele as goeie $\delta \alpha i \mu \omega v$ (deel van die goddelike in die mens) is daar ook 'n irrasionele, slegte $\delta \alpha i \mu \omega v$ wat op die mens 'n invloed uitoefen (vgl. Edelstein, 1936:314).

Posidonius beweeg in sy etiek nader aan Plato en dit wil voorkom of hy 'n dualistiese antropologie leer, deur die volgende gedagtes van Plato te aanvaar:

* Die mens kan tot volmaakte deugdelikheid opgevoed word (Diogenes Laertius, Lives VII,91).

* Daar moet onderskei word tussen liggaamlike en geestelike emosies (Edelstein, 1936:306, 307).

* Die $\psi v x \eta ́$ bestaan na die dood selfstandig voort (Bevan, 1965:105).

* Die wortel van die kwaad is in die mens self geleë (Bevan, 1965:105).

* Daar bestaan nie net wyse en immorele mense (soos die Stoisyne leer) nie, maar ook diegene wat vordering maak (Diogenes Laertius, Lives VII,91).

Saam met die ander filosowe van die eerste eeu n.C. leer Posidonius ook dat die doel en strewe van die lewe 'n 'natuurlike' lewe is (Diogenes Laertius, Lives VII,87). Anders as die Stoissne ${ }^{40}$ leer hy dat die 'natuurlike' lewe daarin bestaan dat die mens toesien dat die rasionele deel van sy $\psi v \chi \chi_{\eta}$ soveel as moontlik beheer oor die irrasionele deel verkry (Edelstein, 1936:315).

\section{Samevatting}

Die doel van hierdie artikel is die konstruering van 'n waarskynlike sosio-historiese en filosofiese konteks vir die dwaalleer van Kolosse. Die resultaat kan soos volg saamgevat word:

* Die rede vir die dwaalleer in Kolosse was waarskynlik 'n poging van sommige van die gemeentelede om as filosofiese skool sosiale identiteit te vind.

* Die dwaalleer was vermoedelik gebaseer op die kosmologie van Empedokles.

40 Die Stoïsyne leer dat die 'lot' die mens se lewc bepaal, en dat die 'natuurlike' lewe 'n lewc orgegee aan die 'lot' is 
* Die waarskynlikste filosofiese konteks vir die dwaalleer in Kolosse is die eklektiese filosofie van Posidonius.

Hierdie konstruksie van die waarskynlike konteks van die dwaalleer in Kolosse het (in die lig van die struktureel sentrale posisie van die dwaalleer in die brief) belangrike implikasies vir die verstaan van die Kolossensebrief, en maak dit moontlik om die bevrydende boodskap van die evangelie ook in die hedendaagse sosio-historiese en filosofiese konteks effektief toe te pas.

\section{Bibliografie}

ALLEN, RE. ed 1966 Greek Philosophy: Thales to Aristotle Readings in the History of Philosophy London: Collier

BAKE, I 1810. Posidonii Rhodii reliquiae doctrinae Collegit atque illustravit Janus Bake Lugduni Betavorum

BANDSTRA, A.J. 1964. The Law and the Elements of the World An Exegetical Study in Aspects of Paul's Teaching Kampen : Kok

BARROW, R.H. 1967. Plutarch and His Times. Bungay : Richard Clay

BOTHA, J 1989. Semeion Inleiding tot die interpretasie van die Griekse Nuwe Testament Potchefstroom : PU vir CHO

BEVAN, E. 1965. Stoics and Sceptics Four lectures delivered in Oxford during Hilary term 1913 for the Common University Fund Cambridge : Heffer \& Sons

BLINZLER, J. 1963 Lexikalisches zu dem Terminus ta stoicheia tou kosmou bei Paulus Analecta Biblica, 17-18:429-443

BORNKAMM, G. 1952. Die Haresie des Kolosserbriefes Theologische Literaturzeitung. 1(1): $11-20$.

BRENK, F.E. 1977. In Mist Apparelled Religious Themes in Plutarch's Moralia and Lives Leiden : Brill

BRUCE, F.F 1957 Commentary on the Epistle to the Colossians Grand Rapids : Eerdmans

BRUCE, FF 1972. The Message of the New Testament Exeter : Paternoster

CARY, M \& SCULLARD, H H 1975 A History of Rome, Down to the Reign of Constantine London : Butler \& Tanner.

CAIRD, G B 1976 Paul's Letters from Prison (Ephesians, Philippians, Colossians, Philemon) London: Butler \& Tanner.

COETZEE, J C. 1983. Die Blye Boodskap Gids deur die Boeke van die Nuwe Testament Deel 1. Potchefstroom: Pro Rege.

DELliNG, G 1964 otol $\chi \varepsilon \hat{\imath} \alpha$. (In Friedrich, G ed Theological Dictionary of the New Testament Vol. VII Grand Rapids : Eerdmans p 666-686).

DE VILLIERS, P.G.R 1982 Renaissance van die sosiologiese eksegese. Theologia Evangelica, $15(3): 19-33$.

DE VILLIERS, P.G R. 1984. The Interpretation of a Text in the Light of its Socio-Cultural Setting Neotestamentica, 18:66-79

DE WETTE, W ML 1847. Kurze Erkläung der Briefe an der Kolosser, an Philemon, an die Ephesier und Philipper Leipzig : Weidmann

DE WITT, N.W 1954 Paul and Epicuris Minneapolis : University of Minnesota Press

DIBELIUS, M 1927. Handbuch zum Neuen Testament XII An die Kolosser, Epheser, an Philemon. Tübingen. Mohr 
DIELS, H. red. 1903. Die Fragmente der Forsokratiker. (6de Uitgawe.) I, II \& III Berlin Weidman.

DIOGENES LAERTIUS. 1950. Lives and Opinions of Eminent Philisophers. Vol I (The Loeb Classical Library). London : Heinemann.

DUVENAGE, S. s.j. Die dekor van die Nuwe Testament. 'n Kultuur-historiese agtergrondstudie. Pretoria : Interkerklike Uitgewerstrust

EDELSTEIN, L. 1936. The Philosophical System of Posidonius. American Journal of Philo$\log , 57: 286-325$

EDELSTEIN, L. \& KIDD, I.G. 1972. Posidonius I. The Fragments. Cambridge : University Press.

ELLIOTT, J.H. 1981. A Home for the Homeless A Sociological Exegesis of 1 Peter, Its Situation and Strategy. London: SCM.

GODET, F. 1887. Studies on the Epistles of St Paul. London : Hodder \& Stoughton

HANSON, A T. 1974 Studies in Paul's Technique and Theology. London : SPCK

HEINEMANN, I. 1968 Poseidonios. Metaphysische Schriften, I \& II Hildesheim: George Olms.

HENDRIKSEN, W. 1964. The Geneva Series of Commentaries: Colossians \& Philemon London : Banner of Truth.

JACOBY, F. 1926 Die Fragmente der griechischen Historiker, I \& II Leiden : Brill

JAEGER, W.W. 1913. Das Pneuma in Lykeion. Hermes, 48:53, 54.

JAEGER, W W. 1947. The Theology of the Early Greek Philosophers. The Grifford Lectures. Oxford : Clarendon.

JANSE VAN RENSBURG, J.J. 1984. Soeklig. Fokus op Kolossense Pretoria : Heer.

LIGHTFOOT, J.B. 1879. St. Paul's Epistles to the Colossians and to Philemon London Macmillan and Co.

LOUW, J.P. \& NIDA, E.A eds 1988. Greek-English Lexicon of the New Testament Based on Semantic Domains, I \& II. New York : UBS

MALHERBE, A.J. 1977. Social Aspects of Early Christianity Baton : Rouge

MEEKS, W.A. 1983. The First Urban Christians The Social World of the Apostle Paul New Haven : Yale University Press.

MEEKS, W.A. 1986. The Moral World of the First Christians Philadelphia : Westminster Press.

O'BRIEN, D. 1969. Empedocles' Cosmic Cycle A Reconstruction from the Fragments and Secondary Sources. Cambridge : University Printing House

REICHE, H.A.T. 1960 Empedocles' Mixture, Euodian Astronomy and Aristotle's Connate Pneuma. Amsterdam : Hakkert.

REICKE, B 1951. The Law and This World According to Paul. Journal of Biblical Literature, 70:259-276

REINECKER, F. 1980. Sprachlicher Schlüssel zum Griechischen Neuen Testament. Nach der Ausgabe van D. Eberhard Nestle Basel : Brunnen.

RIDDERBOS, H.N. 1960. Commentaar op het Nieuwe Testament: Aan de Kolossensen Kampen : Kok.

RITSCHL, A 1900. Die Christliche Lehre von der Rechtfertigung und die Versohnung, Band 2 Bonn: Marcus \& Weber.

ROBERTS, J.H 1984. Die gevangenskapbriewe. (In Du Toit, A.B. red. Handleiding by die Nuwe Testament V Die Pauliniese briewe: Inleiding en Teologie Pretoria : NGK $p$ 151-152.)

ROBERTS, J H. 1988. Die bedreiging van die gemeente in Kolosse. Hervormde Teologiese Studies, 44(4) 812-828. 
ROBERTS, J.H 1991. Bly by Christus die Hoof: Die Christologiese fundering van heilsbelewenis en lewenspraktyk (In Roberts, J H., Vorster, W S., Vorster, J.N., Van der Watt, J.G. reds Teologie in konteks Pretoria : Orion p 294-320.)

SASSEN, F 1949. Geschiedenis van de Wijsbegeente der Grieken en Romeinen Nijmegen Dekker \& Van de Vegt

SCHIPPERS, R 1954. De Gereformeerde zede Kampen : Kok.

SCHLIER, H 1949 Der Brief an die Galater. Gottingen : VandenHoeck \& Ruprecht

SCHWEIZER, E. 1970. Die "Elemente der Welt" Gal 4:3,9, Kol 2:8,20 (In Bocher O \& Haacker, K., Hrsg Verborum Veritas. Festschrift fur Gustav Stahlin zum 70 Geburtstag Wuppertal : Rolf Brockhaus p 245-259)

SPIER, JM 1959 Van Thales tot Sartre Wijsbegeerte uit de oude en nieuwe tijd Kampen : Kok.

STÖRIG, H J. 1972. Geschiedenis van de Filosofie Band 1. Utrecht, Antwerpen Het Spectrum

THEISSEN, G. 1987. The Shadow of the Galilean London : SCM

UITMAN, J.E 1972. De brief van Paulus aan de Kolossenzen Nijkerk : Callenbach

VAN AARDE, A G 1988 Jesus en die sosiaal-veragtes Henormde Teologiese Studies, 44 829-846.

VAN DE KAMP,W. 1987. Theologie in verandering Kerk en Theologie, 38:303-317

VAN DER WALT, J J \& VAN DER VYVER, GC.P 1968 Ken en vertrou Inleiding tot die boeke van die Bybel en die Dordtse Leerreels. Potchefstroom : Herald

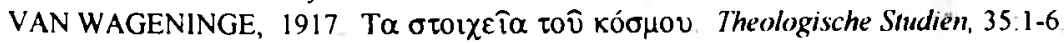

VORLÄNDER, K. 1971 Geschiedenis van de Wijsbegeerte I Oudheid. Utrecht, Antwerpen . Het Spektrum

WIELENGA, G. 1917. Paulus in zijn leven en werk Kampen Kok

WEED, R 1971. The Letters of Paul to the Ephesians, Colossians and Philemon Austin Sweet

YONGE, C D 1902. M Tullius Cicero On the Nature of the Gods, On Divination, On Fate, On the Republic, On the Laws and on Standing for the Consulship London: G Bell \& Sons 
